\title{
METODE PEMANASAN DAN SONIKASI MENGHASILKAN NANOLIPOSOM DARI FOSFOLIPID LESITIN KEDELAI (SOY LECITHIN)
}

\author{
Rini Dwiastuti ${ }^{1,3 *}$, Sri Noegrohati ${ }^{3}$, Enade Perdana Istyastono ${ }^{3}$, Marchaban ${ }^{2}$ \\ ${ }^{1}$ Program Studi S3 Fakultas Farmasi, Universitas Gadjah Mada, Yogyakarta, Indonesia \\ ${ }^{2}$ Fakultas Farmasi, Universitas Gadjah Mada, Yogyakarta, Indonesia \\ ${ }^{3}$ Fakultas Farmasi, Universitas Sanata Dharma, Yogyakarta, Indonesia
}

Received April 1, 2016; Accepted April 12, 2016

\begin{abstract}
Liposomes in topical drug delivery preparation is developed because having a good penetration through the skin. The lecithin which is often used in liposome formulations is soy lecithin. Heating and sonication methods can be done to reduce the size of the particles. This study aims to produce nanoliposom dosage formulations of soy lecithin phospholipids by using a combination of heating and sonication methods to generate liposomes with size < 150nm. The methods of nanoliposomes preparation in this study using a combination of heating $60^{\circ} \mathrm{C}$ and sonication methods for about 30 minutes in the manufacturing process. The results showed that the preparation of nanoliposomes formulation from soy lecithin can be done by using a combination of heating $60^{\circ} \mathrm{C}$ and sonication methods for about 30 minutes.
\end{abstract}

Keywords: liposome, nanoliposome formulation, soy lecithin, sonication

\section{PENDAHULUAN}

Liposom merupakan sediaan farmasi yang dikembangkan dalam dunia farmasi karena liposom memiliki kelebihan, diantaranya meningkatkan efikasi dan indeks terapi serta meningkatkan stabilitas obat dengan sistem enkapsulasi (Akbarzadeh et al., 2013). Lesitin kedelai mengandung asam lemak tidak jenuh yang memiliki kompatibilitas tinggi di dalam tubuh dan penetrasi yang baik. Lesitin kedelai banyak digunakan dalam pembuatan liposom (Kang et al. 2005). Liposom dikembangkan sebagai sediaan topikal karena sediaan liposom memiliki penetrasi yang baik di kulit (Maghraby et al. 2001, 1999).

Pembuatan liposom dapat dilakukan dengan cara konvensional maupun metode novel yang hingga saat ini masih dikembangkan. Metodemetode tersebut membutuhkan waktu yang lama dalam pembuatan. Selain itu, metode tersebut membutuhkan pelarut organik yang bila meninggalkan residu dapat bersifat toksik (Mozafari et al. 2005). Metode pemanasan (metode Mozafari) merupakan salah satu metode novel yang dikembangkan dalam pembuatan liposom tanpa pelarut organik. Metode pemanasan dapat digunakan untuk membuat liposom yang mengandung enzim, vaksin, atau senyawa lain yang peka terhadap pelarut organik (Colas et al., 2007).

Ukuran partikel merupakan parameter sifat fisik yang perlu diperhatikan dalam pembuatan liposom. Salah satu upaya yang dapat dilakukan untuk memperkecil ukuran partikel adalah dengan sonikasi (Akbarzadeh et al, 2013). Ukuran diameter liposom yang dihasilkan dengan cara sonikasi dipengaruhi oleh suhu dan durasi proses sonikasi (Dua et al., 2012). Lama sonikasi juga dapat berpengaruh pada ukuran partikel yang dihasilkan (Dua et al., 2012).

Beberapa faktor yang mempengaruhi sifat fisik suatu liposom menunjukkan bahwa komposisi lesitin kedelai, kecepatan pencampuran, durasi pencampuran dan suhu pencampuran berpengaruh terhadap berbagai sifat fisik liposom (Jahadi et al., 2012). Pembuatan liposom menggunakan metode konvensional mempunyai banyak kendala, antara lain cukup rumit, membutuhkan waktu lama, dan menggunakan pelarut organik yang bersifat toksik. 
Nanoliposom dengan diameter $100 \mathrm{~nm}$ sering digunakan sebagai pembawa dalam sistem pengiriman obat karena mempunyai kemampuan distribusi yang lebih baik (Sułkowski et al., 2005). Sebuah metode yang disebut Mozafari method atau metode pemanasan telah dikembangkan oleh Mozafari (Colas et al., 2007). Penelitian ini bertujuan untuk melakukan formulasi sediaan nanoliposom dari fosfolipid lesitin kedelai dengan menggunakan kombinasi metode pemanasan dan sonikasi untuk menghasilkan liposom dengan ukuran nano.

\section{METODE PENELITIAN}

Bahan yang digunakan dalam penelitian ini adalah fosfolipid lesitin kedelai (Sigma Aldrich), air bidestilata, 4-n-butylresorcinol (SHREEJI Pharma International). Alat yang digunakan dalam penelitian ini adalah blender, ultra turrax, bath sonicator (ELMA), particle size analyzer (HORIBA scientific, JAPAN).

Liposom dibuat dengan mendispersikan 8,70 gram fosfolipid lesitin kedelai dalam $100 \mathrm{~mL}$ air suling pada suhu $60^{\circ} \mathrm{C}$. Fosfolipid lesitin kedelai yang telah terdispersi dalam air suling selanjutnya diblender selama 60 detik. Larutan dispersi fosfolipid lesitin kedelai dihomogenkan menggunakan ultra turrax selama 60 detik dan disonikasi menggunakan bath sonicator selama 30 menit pada suhu $60^{\circ} \mathrm{C}$. Formulasi liposom dibuat dalam 2 formula yaitu liposom tanpa penambahan zat aktif dan liposom dengan menggunakan zat aktif dengan tujuan untuk mengetahui pengaruh penambahan zat aktif terhadap ukuran liposom yang dihasilkan. Zat aktif yang digunakan dalam formulasi ini adalah senyawa 4-n-butylresorcinol. Penambahan zat aktif dilakukan pada proses awal sonikasi dengan menambahkan 0,1 gram senyawa 4-n-butylresorcinol. Liposom yang dihasilkan selanjutnya dilakukan pengukuran ukuran partikel dengan menggunakan alat particle size analyzer (PSA).

\section{HASIL DAN PEMBAHASAN}

Salah satu parameter yang perlu diperhatikan dalam formulasi liposom adalah ukuran partikel yang dihasilkan. Salah satu parameter yang perlu diperhatikan dalam formulasi liposom adalah ukuran partikel yang dihasilkan. Beberapa penelitian menggunakan vesikel kecil dengan rentang diameter 50-150 nm dengan pertimbangan efisiensi kapsulasi, stabilitas dan distribusi dalam sistem penghantaran obat (Liang et al., 2004) (Sułkowski et al., 2005) (Ko and Lee, 2010). Formulasi nanoliposom masih terus dikembangkan hingga saat ini. Banyak upaya telah dilakukan untuk memperkecil ukuran liposom. Energi sonikasi sering digunakan untuk memproduksi liposom dengan diameter yang kecil hingga 15-50 $\mathrm{nm}$. Metode pembuatan liposom yang digunakan dalam penelitian ini adalah kombinasi metode pemanasan $60^{\circ} \mathrm{C}$ dan energi sonikasi untuk menghasilkan sediaan liposom dengan kisaran ukuran 50-150 nm (Liang et al., 2004). Lama sonikasi yang digunakan dalam penelitian ini adalah 30 menit. Metode pemanasan merupakan salah salah satu metode novel untuk membuat liposom tanpa menggunakan pelarut organik, sehingga tidak bersifat toksik (Mozafari et al. 2005).

Pengembangan metode pembuatan liposom yang digunakan dalam penelitian ini adalah penggunaan kombinasi metode pemanasan sebesar $60^{\circ} \mathrm{C}$ dan sonikasi selama 30 menit. Kelebihan dari kombinasi kedua metode ini adalah durasi pembuatan yang lebih cepat dan tidak menggunakan pelarut organik selama pembuatan. Pelarut yang digunakan selama formulasi liposom adalah air bidestilata sehingga tidak meninggalkan residu pelarut organik yang kemungkinan dapat bersifat toksik.

Formulasi nanoliposom dalam penelitian ini dibuat dalam 2 formula, yaitu formula liposom tanpa penambahan zat aktif dan formula liposom dengan penambahan zat aktif. Zat aktif yang digunakan adalah senyawa 4-n-butylresorcinol. Senyawa 4-n-butylresorcinol mempunyai efek hipopigmentasi dengan cara menghambat aktivitas enzim tirosinase dan menekan sintesis tirosinase yang memicu sintesis melanin kulit (Kim et al., 2005; Kolbe et al., 2013). Senyawa ini dikembangkan dalam pengobatan melasma kulit. Aktivitas senyawa ini adalah menghambat enzim tirosinase yang terdapat pada lapisan stratum basal sehingga diperlukan formulasi dalam bentuk nanoliposom untuk dapat menghantarkan zat aktif 
sampai pada stratum basal lapisan kulit. Ukuran liposom yang dihasilkan dalam penelitian ini disampaikan pada Tabel 1.

Tabel 1. Hasil rata-rata ukuran liposom menggunakan particle size analyzer (PSA) Formula liposom
partikel yang dihasilkan $(\mathrm{nm})$

\begin{tabular}{lcc} 
& & $(\mathrm{nm})$ \\
\hline $\begin{array}{l}\text { Formula liposom tanpa } \\
\text { penambahan zat aktif }\end{array}$ & $99,76 \pm 35,57$ \\
\hline $\begin{array}{l}\text { Formula liposom dengan } \\
\text { penambahan senyawa } 4-n-\end{array}$ & $103,85 \pm 51,56$ \\
butylresorcinol & & \\
\hline
\end{tabular}

Hasil pengukuran liposom (Tabel 1) menunjukkan bahwa formula liposom tanpa penambahan zat aktif maupun dengan penambahan zat aktif menghasilkan liposom dengan kisaran ukuran $100 \mathrm{~nm}$. Liposom yang terbentuk biasanya memiliki distribusi ukuran partikel yang heterogen. Ukuran liposom juga berubah seiring dengan waktu penyimpanan (Barenholz, 2001). Ukuran partikel liposom yang dihasilkan dalam penelitian ini juga bersifat heterogen dengan distribusi ukuran 30-150 nm. Kurva distribusi ukuran partikel liposom ditunjukkan pada Gambar 1 dan Gambar 2.

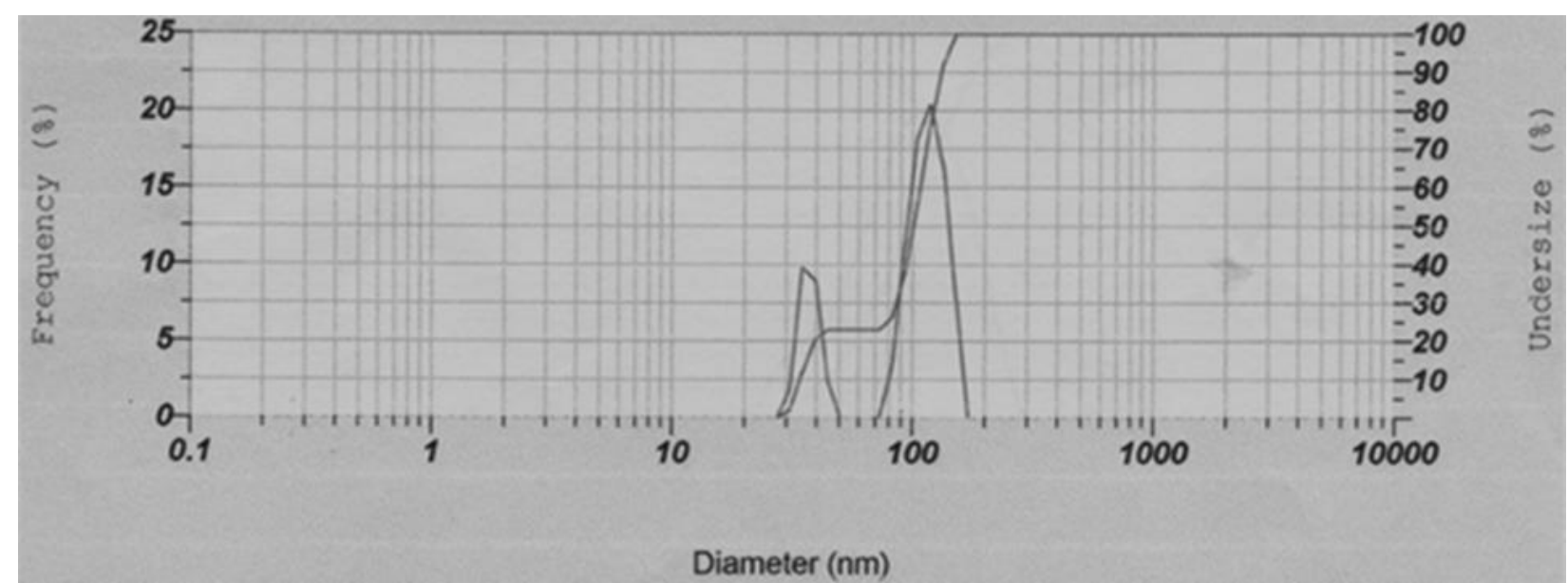

Gambar 1. Kurva distribusi ukuran liposom tanpa penambahan zat aktif

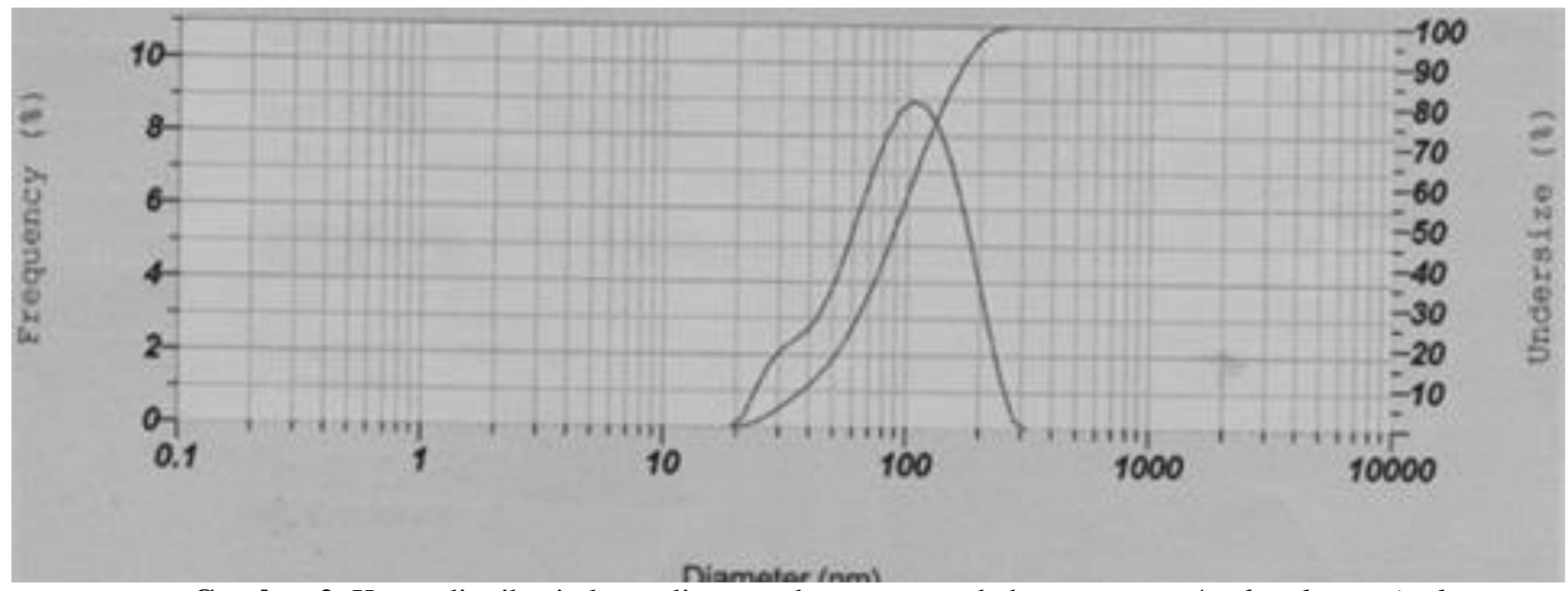

Gambar 2. Kurva distribusi ukuran liposom dengan penambahan senyawa 4-n-butylresorcinol 
Gambaran kurva distribusi ukuran liposom tanpa penambahan zat aktif (Gambar 1) menunjukkan hasil sebaran distribusi ukuran partikel tidak normal sedangkan gambaran kurva distribusi ukuran liposom dengan penambahan zat aktif berupa 4-n-butylresorcinol (Gambar 2) menunjukkan hasil sebaran distribusi ukuran partikel normal. Polydispersity Index (PI) yang digunakan dalam pengamatan ukuran partikel dengan menggunakan Dynamic Light Scattering (DLS) memenuhi persyaratan (Iego, 2012) untuk larutan polydisperse yaitu untuk ukuran partikel 100-300 nm persyaratan PI adalah < 0,3. Pada pengamatan liposom tanpa penambahan zat aktif nilai PI adalah sebesar 0,204 dan untuk pengamatan liposom dengan penambahan senyawa 4- $n$ butylresorcinol nilai PI sebesar 0,286.

Ukuran liposom yang dihasilkan dalam penelitian ini serupa dengan penelitian Ko dan Lee et al. yang menghasilkan liposom dengan rata-rata ukuran $98 \pm 48 \mathrm{~nm}$. Perbedaan dengan penelitian Ko dan Lee et al. adalah pada metode formulasi yang digunakan. Metode formulasi yang digunakan dalam penelitian ini adalah kombinasi metode pemanasan dan sonikasi sedangkan penelitian Ko dan Lee et al. menggunakan metode dehydrationrehydration sehingga memerlukan waktu yang lebih lama dan menggunakan pelarut organik dalam proses formulasinya. Nanoliposom dengan ukuran $100 \mathrm{~nm}$ yang berisi bahan aktif memiliki stabilitas sebagai sediaan kosmetik bahan dan sistem penghantaran obat secara topikal (Ko and Lee, 2010).

\section{KESIMPULAN DAN SARAN}

Formulasi sediaan nanoliposom dari fosfolipid lesitin kedelai (soy lecithin) dapat dilakukan dengan menggunakan kombinasi metode pemanasan $60^{\circ} \mathrm{C}$ dan lama sonikasi 30 menit. Saran dari penelitian ini adalah perlu dilakukan penelitian lebih lanjut terkait optimasi suhu dan lama sonikasi dalam pembuatan nanoliposom dan pengamatan morfologi bentuk liposom yang dihasilkan dengan menggunakan Transmission Electron Microscopy (TEM).

\section{UCAPAN TERIMAKASIH}

Ucapan terimakasih disampaikan kepada DIKTI atas dukungan finansial melalui dana Hibah Penelitian Disertasi Doktoral tahun 2016 dan Dina
Christin Ayuning Putri yang telah membantu dalam pelaksanaan penelitian ini.

\section{DAFTAR PUSTAKA}

Akbarzadeh, A., Rezaei-sadabady, R., Davaran, S., Joo, S.W., Zarghami, N., 2013. Liposome: classification, preparation, and applications. Nanoscalereslett, 8, 1-9.

Barenholz, Y., 2001. Liposome application: problems and prospects. Curr. Opin. Colloid Interface Sci, 6, 66-77.

Colas, J.C., Shi, W., Rao, V.S.N.M., Omri, A., Mozafari, M.R., Singh, H., 2007. Microscopical investigations of nisin-loaded nanoliposomes prepared by Mozafari method and their bacterial targeting. Micron, 38, 841847.

Dua, J.S., Rana, A.C., Bhandari, A.K., 2012. Liposome: Methods of Preparation and Applications. Int J Pharm, 3, 14-20.

Iego, S. a N.D., 2012. Guide To Dynamic Light Scattering Measurement and Analysis. NanoComposix, 1-7.

Jahadi, M., Khosravi-Darani, K., Ehsani, M.R., Mozafari, M.R., Saboury, A.A., Seydahmadian, F., Vafabakhsh, Z., 2012. Evaluating the effects of process variables on protease-loaded nano-liposome production by Plackett-Burman design for utilizing in cheese ripening acceleration. Asian J. Chem, 24, 3891-3894.

Kim, D.-S., Kim, S.-Y., Park, S.-H., Choi, Y.-G., Kwon, S.-B., Kim, M.-K., Na, J.-I., Youn, S.W., Park, K.-C., 2005. Inhibitory effects of 4n-butylresorcinol on tyrosinase activity and melanin synthesis. Biol Pharm Bull, 28, 2216-2219.

Ko, S., Lee, S., 2010. Effect of nanoliposomes on the stabilization of incorporated retinol. $J$ Biotechnol, 9, 6158-6161.

Kolbe, L., Mann, T., Gerwat, W., Batzer, J., Ahlheit, S., Scherner, C., Wenck, H., Stäb, F., 2013. 4-n-butylresorcinol, a highly effective tyrosinase inhibitor for the topical treatment of hyperpigmentation. JEADV, 27 Suppl 1, $19-23$.

Liang, X., Mao, G., Ng, K.Y.S., 2004. Mechanical properties and stability measurement of cholesterol-containing liposome on mica by 
atomic force microscopy. $J$ Colloid Interface Sci, 278, 53-62.

Maghraby, G.M.M.E., Williams, A.C., dan Barry, B.W., 1999. Skin Delivery of Oestradiol from Deformable and Traditiona Liposomes: Mechanistic Studies. J Pharm Pharmacol, 51: 1123-1134.

Maghraby, G.M.M.E., Williams, A.C., dan Barry, B.W., 2001. Skin delivery of 5-fluorouracil from ultradeformable and standard liposomes in-vitro. J Pharm Pharmacol, 53: 1069-1077. Mozafari, M.R., 2005. Nanoliposomes: From Fundamentals to Recent Developments. Trafford Publishing, Victoria, B.C.

Sułkowski, W.W., Pentak, D., Nowak, K., Sułkowska, A., 2005. The influence of temperature, cholesterol content and $\mathrm{pH}$ on liposome stability. J Mol Struct, 744-747, 737-747. 